\title{
7 Refugee scholars then and now
}

\author{
Carol Bohmer
}

\section{Introduction}

There is a significant body of research about scholars who fled Europe in the 1930s and 1940s. Less has been written, however, about scholars at risk of persecution in the current period. In many ways the factors leading to the need for flight by scholars are similar: chaos caused by civil war and unrest, persecution of those who speak out against a ruling regime and those from persecuted minorities. There are also, however, many differences in those scholars who have sought safe haven away from their conflict torn homelands then and now. This chapter will describe the situation of both groups of refugee scholars and will conclude that current refugee scholars are subject to a perfect storm of difficult conditions for both academics and immigrants, which creates a uniquely precarious situation for them. Academics generally are currently suffering the effects of years of neoliberal changes to the system, in which their jobs are in constant jeopardy, and in which many of them are part of the gig economy, without job security or benefit. ${ }^{1}$ Whilst refugee scholars are affected by these changes, they also suffer from the widespread tightening of immigration controls, which can seriously limit their ability to remain in their country of refuge. In my interviews I spoke to scholars who are having a very tough time finding a permanent job in their host country, as well as those who move from one short-term appointment to another.

The chapter will also use the plight of scholars at risk to examine the ways in which the law and policy of asylum have changed in the years since the passage of the Convention Relating to the Status of Refugees passed in 1951. This Convention, and the Protocol which expanded it in 1967, was passed in reaction to the horrors of World War Two, after the flight of those scholars who left in the 1930s and 1940s. Even though refugee scholars fit readily into the definition of the Convention, its current application makes it an inappropriate tool to benefit them.

\section{The Interviewees}

In the chapter, I use in-depth interviews with refugee scholars mostly in the UK, but also in the US and Europe as a basis for analysis of the issue. I conducted interviews during 2019 with a total of 16 refugee scholars, four in the

DOI: $10.4324 / 9781003092421-10$ 
US, eight in the UK, three in Europe and one in South Africa. ${ }^{2}$ I constructed my sample through personal contacts from my pro bono work with refugees and asylum seekers, both in the US and the UK, and through contacts with colleagues. ${ }^{3}$ The sample is, of course, not representative; such a sample would not be possible. Finding refugee scholars to interview was not easy; many refugees are reluctant to talk about their past. Assessing representativeness is also difficult because there are no general statistics about outcomes for refugee scholars, as those organisations who work with them do not keep such figures. The majority of the interviews were conducted in person, the rest on the phone, and were based on a few specific questions ${ }^{4}$ which I used to open the conversation rather than requiring answers to them all. Most of the interviewees were willing for me to use their real names; two people were not, and in those cases, I changed their names and identifying details to protect them.

\section{Refugee scholars then and now: an overview}

To begin with, it is important to clarify what I mean by the term refugee scholar. The term refugee can be a legal one, as defined in the 1951 Convention on the Status of Refugees, Article 1A(2), as someone who has a, well-founded fear of being persecuted for reasons of race, religion, nationality, membership of a particular social group or political opinion, is outside the country of his nationality and is unable or, owing to such fear, is unwilling to avail himself of the protection of that country."

Refugee is also used more broadly to mean someone who feels they have to leave their native country. There are other terms, for example, exile and émigré, which appear to be synonyms for the second definition, and the term used by CARA (Council for Assisting Refugee Academics, which works to provide academic appointments in the UK), "scholar at risk." The American counterpart of CARA, Scholars Rescue Fund, calls them "threatened and displaced scholars." The distinctions matter, because whether or not one fits into the legal definition of refugee may be important when it comes to acquiring legal status in the country to which the scholar has fled. In this chapter, I consider those that I interviewed to be refugees, though, as we shall see later in the chapter, most of them have never had that legal status officially recognised. The status of refugee is also relevant to the scholar's self-definition, which varies considerably from scholar to scholar. Here I use the word in both the legal sense and the broader sense, depending on the context. Whatever it is called, this status is usually psychologically difficult for the scholars who fled; it is rarely something that can be left behind, but is rather a central part of the person's psyche for an extended period. "What it means to be a refugee cannot be described in the simple terms of finding a job and adjusting to foreign customs. It is a way of being, constantly lingering between arrival and departure."5

\section{Scholars then and now}

The experiences of those who fled then and those who flee now are both similar and different. They were similar in that refugee scholars suffered from 
prejudice (antisemitism then; anti-Islam sentiments now) as well as suffering from a similar sense of disruption and insecurity engendered by their flight. The situation was, however, different in several ways. First the scholars then were more likely to be senior members of the profession, and therefore known to their potential hosts. ${ }^{6}$ Thus, they had a somewhat easier time both getting out and integrating into the academic community. They also arrived at a time when academic institutions were expanding rather than contracting, as is the case now. ${ }^{7}$ The focus of those working to bring scholars out is somewhat different as well. Current refugee scholars are more likely to be recent graduates or to have interrupted their studies as a result of the persecution in their home countries. The universities in the host country are therefore more concerned with helping the scholars finish that education, rather than accepting senior scholars who could add lustre to the university. ${ }^{8}$

Because many of the scholars who fled in the 1930s and 1940s were established scholars, with international reputations, they already had contacts with colleagues; some were sponsored by US and British academics. The focus on the work of those who were most successful may, however, paint an overly rosy picture of their experiences, hiding the fact that for many of them, exile meant permanent insecurity and marginalisation, just as it does today. ${ }^{9}$

Nowadays refugee academics are more likely to come from places where their universities are less well known, and the scholars are not in a position to enhance the reputation of potential host institutions. Some of them are PhD students and postdoctoral researchers, rather than established academics. Also, the academic environment was very different in the 1930s and 1940s; then university education was expanding and those who were lucky enough to get full-time positions found welcoming universities with better facilities and libraries than they were used to, as well as more responsive students. ${ }^{10}$ Now scholars who flee do so at a time when many universities are undergoing major reductions in full-time, tenure track positions, and provide a much less welcoming environment, because tertiary education has become a business. As a result, there are far fewer opportunities available to current refugee scholars. This is not to say it was all easy for scholars who fled in the 1930s and 1940s; many of them had similarly difficult experiences as those of refugee scholars today. For example, some had trouble finding full-time jobs, and wandered from place to place. ${ }^{11}$ It is interesting that, despite prejudice which clearly existed toward the refugees,

By all accounts, this absorption of German and Jewish refugee scholars after 1933 into American institutions of higher learning despite an antisemitic and anti-German atmosphere was of a durable nature: by 1947, 77 percent of scholars exiled in 1933 had obtained faculty positions. ${ }^{12}$

This may have been because most of those who found their way to the US were sponsored by other academics. Even for those who found positions, Lebow describes extensive antisemitism (compounded by anti-immigrant sentiments) which the Jewish scholars faced at US universities. ${ }^{13}$ 
There are now several organisations in different parts of Europe and the US, who work to bring scholars from countries of war or civil unrest, for humanitarian reasons. By contrast, Siegelberg describes US institutions during the 1930s and 1940s as having the goal of bringing out potential Nobel Prize winners, for the benefit of the host country. In Britain, "academics involved with CARA were motivated by humanitarian concerns and a commitment to academic freedom rather than the politics of national prestige."14

Some of the current interest in refugees and scholarship is focused on academic institutions finding ways to provide refugees with the education that their flight interrupted. ${ }^{15}$ Many refugees find it difficult to restart their education once they arrive in their host country. Language and financial problems, not knowing how the system works, can be challenging. So, universities are providing scholarships for refugee students, and organisations are finding other ways of assisting. Recently, for example, there was a conference in Edinburgh on long-term approaches of higher education to supporting refugees and atrisk scholars. ${ }^{16}$ One NGO, RefuAid, works with universities to offer advanced English training to refugees so they can study at UK universities. A German professor of finance has set up a website to help refugee academics find jobs. ${ }^{17}$

\section{Safe haven just for now or forever?}

One of the most difficult issues for refugee scholars (and indeed for all refugees) is when and whether it is possible to return home. The refugee scholars of the 1930s and 1940s were in the US for the duration of the war, though many of them never returned. After the war, almost all of the French who left Europe for the US went back to France, including the entire French contingent at the New School, but virtually none of the other refugee scholars returned..$^{18}$ Only a very few Germans in the US went back; one went back to Frankfurt to rebuild and democratise his university department, but the others, most of whom were Jewish, stayed in the US, perhaps out of an unwillingness to trust the post-war regime's attitudes to Jews. Some, however, like Hannah Arendt, refused for years to accept that their exile was permanent. ${ }^{19}$ Most of the scholars who went to the UK also stayed there.

Current refugee academics want to return home. Stephen Wordsworth, Director of CARA, says "Almost all our Fellows are clear that they want to return home, when they can. For example, a number of those who left Syria because they came under attack from extremists are now considering return, but many are still unsure about how they would be received, so are waiting a little longer to see how things develop." 20

As Wordsworth makes clear, many of the current refugee scholars are waiting for changes which would make it possible for them to return. Almost every refugee I have met over many years of working with them, cherishes the hope of returning to their country, in which the problems which caused them to leave have miraculously disappeared. Over the years, as they adjust to their new life that hope loses salience and becomes a dream, a fantasy, rather than a realistic possibility. The passage of time itself makes it more and more 
difficult to return, because they have been changed by their refugee status in the new country, both as a result of the passage of time and new experiences. When asked if he would go back, Weysi, a Kurdish academic, now a German citizen, said "After all I went through it would be difficult to live in Kurdistan." Firas, a Syrian doctor who has been away from Syria for some years, also responded negatively: "Never. Because of the social, religious and political oppression, I would be very tied [i.e. limited]."

Refugee scholars often have a particular need or desire to return to help the country they left. Magdalene, for example, wanted to go back to Cameroon to teach nursing in the university where she studied before leaving. However, with the passage of time, and the resulting natural integration that happens over time, it becomes less likely, though the yearning may continue. Since obtaining refugee status in the US, Magdalene has married another refugee, from a different country and now has an American child, so the chances she will return are slight. Afra (not her real name), who is from Syria, told me both that she wanted to go back and that she could not go back to Syria in the same sentence, illustrating the conflict and ambivalence of being a refugee scholar.

Other refugees have no wish to go back, except perhaps for short periods, to help rebuild the country and its institutions. Firas now thinks of himself as an American, though he did say he'd be glad to return temporarily after the war ended to help rebuild. After a number of years in the US, he thinks of himself as an immigrant, rather than a refugee, although, ironically, he is one of the relatively few scholars I interviewed who is applying for asylum.

Some refugee academics still cannot return, however much they may want to. Yonas an Eritrean, who left a number of years ago, first to get a $\mathrm{PhD}$ in Sweden, then to study and work as an academic in the US, told me: "I could go back to Eritrea but the situation is unpredictable. If I went in I could go in with an ID card, I'd have to sign a paper to say I regret what I did. If they want, they can hold me."

For Mehmet, the situation is also impossible: "They wouldn't hire me in Turkey, I am probably still on the blacklist."

How painful this is for the exiled scholars varies, too, from Firas who doesn't seem at all concerned about it to Magdalene who has agonised about it. The pain for many refugees may be exacerbated by having had to leave their families behind; to the extent that other family members got out, this pain is mitigated somewhat. Taleen is now a postdoc in California; her entire family has left Iraq, either for Europe or the US (one sister lives nearby), which has helped her in adjusting to exile. The refugees who fled in the 1930s and 40s also suffered great anxiety about the fate of their families in Europe. ${ }^{21}$

After the war, the issue of return was clearer. Refugee scholars who had fled Europe in the 1930s had the choice about whether to return to their homelands or whether to stay permanently in the host country. Because many of them had permanent jobs, the choice to stay or leave was real. This choice is more complicated for refugee scholars now because of the very different nature of the visa regimes in host countries, as well as greater limits on academic jobs. In addition, the conflicts that caused some academics to flee have 
no clear ending, as did World War II, making the timing of a decision to return more fraught.

\section{The post-award trajectory of refugee scholars: temporary or permanent solution?}

It is difficult to ascertain what happens to those refugee scholars who are supported by the various agencies for a short term (usually one or two years) after their fellowship has finished. The organisations generally expect that the scholar will have developed their career and their contacts to enable them to find a job. While these organisations are happy to provide statistics about the number of scholars they assist, they do not collect information about what happens to them after the fellowship ends. ${ }^{22}$ CARA's website, for example, provides a number of profiles of the successful scholars, who have found jobs or won awards, but it is impossible to determine what percentage this represents of all those who are helped. Some of my interviewees were having difficulty finding work, and others moved from one short-term appointment to another. It is difficult to know in the absence of data how representative they are.

CARA views its mission as primarily getting people who are persecuted out of the country, as has been the case since its founding in the 1930s. As the head of the organisation said: "It is now still a rescue mission. They help people who contact them." 23 It provides a bolt hole until the academics can go home, but the problem is that for some of them that prospect is years away, if it exists at all. "We don't deal so much with 'refugee scholars' these days, if by that you mean people seeking permanent refuge, but Cara is one of the global leaders in providing temporary refuge for academics needing urgently to escape, and to find somewhere safe to continue their work until they can eventually go home again." 24

In some ways, these programs are problematic; they provide safe haven for people fleeing, but only for a short period. Then they are on their own either to return home or find a job here. Given that jobs are very hard to find, the fear of having to go back to the same situation they fled is ever present. As one author points out: "the scholars most likely to receive support are not necessarily those who are at greatest risk. Those who receive the fellowships tend to be scholars who have been educated in North American and European universities and have published extensively in the English language, or in French or German, in high-ranking journals." 25

The issue is whether welcoming refugee academics is a temporary solution so they can hide out until things improve at home, or whether it is to find a permanent home away from a country where the situation is not likely to change for a long time. It mirrors a fundamental question about the nature of asylum, as temporary or permanent, which asylum law and policy in host countries struggles with. Different receiving host countries have different approaches to this issue.

Obtaining asylum may not be a permanent solution for some refugee scholars, because many host states initially award asylum status for a 
temporary period only, which is usually made permanent after a period of years. ${ }^{26}$ Until recently, the UK routinely gave Indefinite Leave to Remain (ILR) after five years, but nowadays it is no longer automatic. ${ }^{27}$ The US is unusual in giving the successful asylum permanent residence one year after granting asylum.

In addition to the practical issues of survival and visa problems, the psychological implications of this temporary situation are profound for refugee scholars. Many of them suffer from Post Traumatic Stress Disorder (PTSD) from their experiences of persecution in their home countries before fleeing. Megan Berthold, a psychologist with many years of treating refugees, says: "Some academics who are targeted for persecution are able to secure short term visas to enable them to leave their unsafe environments and work in Universities abroad. While this affords them temporary relief and safety, the sense of safety feels precarious for many. They remain in a state of insecurity about the future, living in fear that they may have to return to their home country where their life and security may be in danger. Psychologically, such temporary status is much harder than if they were able to obtain asylum or another longer term or permanent legal status. Living under the stress associated with temporary status may also take a toll on their physical health."28

Many refugee scholars feel the pain of this temporary state. For example, Leila, from Azerbaijan, described her situation this way: "I am a nomad, moving all the time from one place to another, sometimes I have no money, so I housesit, petsit. I need a place to store things." Naif also uses the word nomad to describe this temporary life: "As for me, I still live in Austria, continuing with my work and life with academic nomadism as the main mode of being and working, as it were."

\section{Am I a refugee?: self-definitions}

There is a range of ways in which refugee scholars identify themselves. Kmak and Farzamfar discuss this for scholars exiled from Nazi Germany in the 1930s and 1940s, as well as for current refugee scholars. Some refugee academics see themselves as refugees first, while others emphasise their identity as academics. ${ }^{29}$ When I asked Weysi about his history as a refugee, he said immediately that he was not a refugee, not anymore; now he was a German citizen. Prosper, a human rights lawyer from Zimbabwe, defines himself as a refugee, even though he has a visa as an academic. However, he chose not to apply for asylum despite his self-perception as a refugee. "It is taking too long to get asylum, the process takes many years, and in the meantime, you can't leave, go to international conferences."

How long a refugee keeps their identity as a refugee is another important factor in the post-flight adjustment of refugees. In my experience, most refugees are anxious to put their past behind them and see themselves as something more than "only" a refugee. But the new identity is influenced by their experiences in the host country, and often contains elements of being a refugee. As Weysi said: "I am a refugee/activist and also an academic, I combine 
all three approaches." Firas said that he felt like an immigrant, but he also added "I feel a refugee by proxy because both of my siblings were able to get a visa to visit me, they decided to stay in the US and apply for asylum."

For some refugee academics, however, it is very hard to let go of the injustice that forced them to flee. It may be easier to put their past behind them if their academic work is unrelated to their experiences, so physical scientists are in an easier position than social scientists. Mohamed, from Egypt, whose field is maritime navigation, has difficulty letting go of the past. He had a huge lawsuit, which has lasted six years, against the university which fired him without merit, for political reasons. He is now torn between continuing to fight the authorities from abroad to get compensation and continuing his academic work in the UK. Unlike many other refugee scholars, Mohamed was not brought out by an NGO, but came on his own and obtained asylum in the UK. He has no current academic affiliation and very few contacts so starting again is very difficult. Before he can even begin to get back to research he would have to find an academic "home."

Connected to one's self-definition as a refugee or something else, are the perceptions of those around the scholars. Several of those I interviewed reported that their colleagues were ignorant of their history, or made them feel like an outsider. Mehmet said: "I'm finding it difficult to explain to people who I am." Because he feels uncomfortable with his colleagues, he spends most of his time in another city with his wife. Syrian Hassan (not his real name) was completely ignored by his colleagues for the whole time he was in their department. Similarly, Svensson discusses the implications of issues of ambivalence and belonging in the group of refugee scholars he interviewed. ${ }^{30}$

\section{The substance of scholarship: then and now}

The relationship between an academic's scholarship and their experiences as a refugee range from no connection to one in which one's experiences form the basis of one's research. For the scientists that I interviewed, there is usually no connection between their work and the fact that they fled their homeland. They see themselves as scientists who happen to be refugees, rather than "refugee scholars." Firas, who, as mentioned above, devoted his life to getting out of Syria, is now an academic doctor and even though he is in the process of applying for asylum, his refugee status has nothing to do with his work.

For those social scientists who work on the geographical area they left, the problem is a particular one: they may be both scholars and activists. Some of them complain that they are not taken seriously as academics, but are assumed to be nothing more than spokespeople for the cause that led them to flee. Naif said: "You are, as a Kurdish academic, you are perceived as being biased, politically engaged. I think this is very unfair, and in some cases, almost racist prejudice. I am dedicated to the same issues and also a very good academic."

Some refugee academics have been more successful in using their past for the benefit of their current work. Eric's scholarship focuses on diplomacy, state sovereignty, and the state of refugees, and he uses his personal 
experience as a refugee, especially the non-personhood of the refugee and the recognition of obligations. Ironically, he uses his connections with the members of the government in his home country, Burundi, to provide them with advice about policy issues.

Weysi's work is directly related to his status as a Kurdish refugee. As he says in an article he published on the subject:

My experiences, which are rooted both in my homeland and in Germany, have now become the field. I place my experience in relation to those of the Kurdish refugees I have interviewed, as an object of study. These memories of suffering transgress space and time in my life and constantly come up in my dreams, during conversations with other refugees, and in my social interactions. ${ }^{31}$

Weysi discusses the issue of academic objectivity in the context of his special position as a refugee scholar researching the area in which he has significant personal experience:

While objectivity in research should typically be valued, I argue that through bringing in my own position as a refugee researcher, I can contribute to a deeper understanding of the importance of self-reflectivity in field research and also bring a critical perspective to established discourse on the integration of recently-arrived refugees. ${ }^{32}$

For some, being a refugee may be an unwelcome constraint. Vatansever points out: "in accordance with the entrenched common practice to confine Non-Western scholars to regional studies, the Peace Academics in European exile are persistently expected to give talks, interviews, and lectures and do research on Turkey exclusively - regardless of their actual disciplines and research interests." 33

The case of Weysi illustrates the various ways in which one's refugee experience colors one's scholarship. Lebow describes a number of refugees of the 1930s whose work was generally informed by their background and as a result their scholarship benefited from their earlier experiences. ${ }^{34}$

Some refugee scholars continue to work in the area they worked on before leaving, but with varying degrees of difficulty. Afra, for example, is an economist who worked on issues in Syria and the Middle East. Her exile status constrains the work she would like to do. She said:

It is not easy to work, because I'd like to be able to work in Syria, couldn't do data in Syria. It is not easy to get funds for the Middle East, they are interested in funding Africa. I am working on my previous work, nothing new until now.

Mehmet's work is less constrained by being outside his country which is the focus of his research: 
I am still working on political economic issues in Turkey. I can do it from here. The 2001 crisis in Turkey led to the Justice and Development Party, Erdogan. ... I work with data, with theories, statistics. I am now working on Sovereign Wealth funds, interviews with officials would be good, but the system isn't very transparent anyway.

For Naif, there is no change in his scholarship: "There is no shift/change in my academic focus. I was working before my suspension on the same topics. I have been working on modern history, the constitution of Turkey, Ottoman/ Kurdistan-modern history, political parties."

Some scholars, by contrast, are forced to change the work they do as a result of their exile. In Zimbabwe, Prosper was a human rights lawyer. Now he is an academic in the Netherlands working on "corruption and human rights, connecting the two. My situation forced me to do something different. Sometimes I get frustrated, I gravitated to academics by default. I can't practice." His work is still clearly influenced by his experiences in his home country, which gave him a perspective and the experience to be able to undertake his current research.

\section{The limits of asylum}

The status of refugee was enshrined into law after World War II in the 1951 Convention Relating to the Status of Refugees. The need for protection came from recognition of the failure of countries to offer safe haven from the Holocaust. For those scholars fleeing in the 1930s and 1940s there was no official status of refugee; those who obtained visas would have received ordinary visas, because of the sponsorship of other scholars, or their universities. Özdemir et al. point out the difference between then and now:

Where the majority of exiled academics during the 1930s and 1940s were left stateless ... today's exiled scholars from Turkey often do not seek asylum in their host society and instead obtain work permits via temporary fellowships or grants. These scholars in exile do face a high risk of becoming stateless or stuck in their host country because their passports have been cancelled by the Turkish state. ${ }^{35}$

In theory, refugee scholars who have been persecuted by their governments for their work or their political opinions are perfect candidates for asylum. In practice asylum isn't much use to the current scholars trying to flee, for reasons I shall discuss below.

Asylum has its origins in international criminal law. ${ }^{36}$ It was initially intended to protect fugitives from extradition by their country of origin, when the reason for the extradition was determined to be unjust, i.e. persecution. In a world of open borders, this was the only reason a person would need the protection of asylum. Nowadays, asylum is considered to serve both a humanitarian purpose and a political one, viewing persecution as one kind 
of harm which causes someone to flee. Many scholars have recently suggested that the system is no longer fit for purpose, because so many refugees are fleeing climate change and general violence for which the Convention is inappropriate.$^{37}$ Price argues that it is the refocus from purely political concerns toward humanitarian relief which muddies the waters and makes less clear the original, true purpose of asylum..$^{38}$

Asylum law and policy has changed dramatically over the last several decades, as a result of both the refocus toward a human rights approach and also the events which precipitated the flight of large numbers of refugees to the global north. ${ }^{39}$ The breakup of the former Yugoslavia led to the flight of hundreds of thousands westwards. The fall of most communist regimes also made it possible for thousands to leave countries where exit had previously been blocked. The plight of the millions of refugees fleeing the war in Syrian and other repressive countries (e.g. Eritrea) is still being dealt with by the EU. These events have put the issue of asylum on the public agenda and led to a variety of mechanisms by governments to stem the flow of asylum seekers. ${ }^{40}$ The underlying theme of these restrictions in granting asylum is the view that asylum was never intended to be a way of shielding vast numbers of people from the problems of civil war and repressive governments. Instead it is an individual legal decision on the merits of the claim by someone who has managed to reach safety. The traditional concept of asylum was that it was a moral responsibility of liberal democracies to provide safety to those fleeing persecution and to make a judgment about the unethical behavior of the original country. ${ }^{41}$ However, nowadays, the public in those countries which have received large numbers of asylum seekers are not concerned about moral responsibility but instead about being overwhelmed by this influx as well as by the perceived security risks such arrivals present delineate several narratives about refugees in the recent crisis in Europe, one of which is the refugee as security threat. ${ }^{42}$ Racism plays its part in the current perception of refugees, as does compassion fatigue. Many of the current asylum seekers come from Africa, or from the war in Syria which has been going on long enough that people have run out of compassion for their plight, especially for those who are different and therefore hard to identify with.

Governments have responded to this change in attitude to asylum seekers by putting in place a number of restrictions to limit both the arrival of asylum seekers and their chance of being granted asylum. ${ }^{43}$ The efforts of the EU to cut off the routes to Europe by Syrians and others seeking asylum are well known. There are also a number of bilateral agreements designed to return asylum seekers either to their homelands or to third countries. The US has recently been returning asylum seekers to Mexico to await a hearing, making it much harder for them to mount a credible claim. When someone has been able to make an asylum claim, there are extensive delays in both the UK and the US, leaving the asylum seeker in limbo, unable to travel and unable, in the UK, to work. Hearing officers and judges both in the US and UK are pressed to deny as many claims as possible, generating what has become known as a "culture of disbelief." In this culture, scholars argue, 
applicants are presumed to be lying in their claims, with little effort on the part of the authorities to listen objectively to the substance of the claim. ${ }^{44}$

The refugee scholars who are the subject of this chapter are affected by the current asylum situation. Those who are brought to the UK by CARA are strongly discouraged from applying for asylum. Stephen Wordsworth argues that universities who sponsor academics would rather not have them claim asylum as it takes too long, though it may also be that they are concerned about the future of the program, if the Home Office sees short-term visas as a way of getting into the country to apply for asylum.$^{45}$ For that reason, short-term visas are used in the UK and also the US. It is certainly true that applying for asylum is an increasingly drawn-out process in both countries, often taking years before asylum is granted. In the UK, an asylum applicant is not permitted to work, whilst in the US the applicant can work after several months have elapsed from the date of the application. In both countries, the applicant has to remain in the country while the applications wends its way through the system.

As mentioned above, the real problems arise after the short-term academic position and its short-term visa have finished. Stephen Wordsworth, director of CARA, said: "There is the hope that they can go home after the time they have here. Finding a permanent job is an issue." ${ }^{46}$ This is a nice hope, but I personally have never met anyone who could go home after the expiration of their short-term, usually two-year, visa. For example, the Syrians who make up a significant proportion of those being helped by organisations such as CARA cannot go home now. Hassan, a Syrian who claimed asylum after he had been in the UK, was very clear that he could not go back: "Assad is consolidating his power but one still can't go back." When Hassan first came to the UK, he said he was discouraged by CARA from claiming asylum. When he decided he would have to claim asylum anyway, because he had no other option, the Home Office asked him why he didn't claim asylum when he first arrived, with the implication that his was not therefore a genuine claim. More than a year later, his asylum claim is still working its way slowly through the system. Meanwhile, he cannot work, nor can his wife, so he is living on the minuscule amount paid to him by the UK government, and suffering severe psychological distress. He can't look for a job outside the UK, because the Home Office has his passport and he is afraid of trying to get another one from the Syrian Embassy.

Whilst Hassan has no choice other than to apply for asylum to avoid going back to Syria, other scholars are luckier, because they have other options. Mehmet, for example, is married to a British citizen, which, at least in theory, makes his visa situation much easier. But even having the opportunity to apply for a spouse visa can limit his options: "once you apply for a spouse visa, you get $2 \frac{1}{2}$ years twice; what if I find a job in Canada? My wife's family, their health is deteriorating, so she might want to stay (in the UK)."

Leila was also lucky; she applied successfully for a Tier 1 visa (exceptional talent), which is a very difficult visa to obtain. She got very strong letters from colleagues, in support. "I didn't take it seriously. The Tier 1 visa is called the Leonardo da Vinci visa." 
Some scholars, like Leila, don't want to view themselves as asylum seekers: "it was as if I was defeated by the government, psychologically it was very difficult to accept." For others, it works the other way. Magdalene came to the US as a Fulbright scholar to get a PhD in nursing, with the goal of teaching nursing at a university. The lawyer who represented her was convinced she would get a visa in this capacity, because of a major shortage of nursing professors. Magdalene wouldn't hear of it because she needed to have her persecution in the Cameroon recognised, which she believed would come with a grant of asylum.

It is ironic that, despite the fact that refugee scholars easily fit into the asylum criteria, in practice current asylum law and policy doesn't work for them. They are forced to find another visa if they want to stay in the US or UK after the expiration of their short-term visa. If that is not possible, as is the case for Hassan, refugee scholars pay a huge professional and psychological price for having to apply for asylum.

\section{Precarity in employment and immigration: the perfect storm}

The term "precariat" has been used recently by scholars examining the results of globalisation and neoliberalism. According to this view, a class of precarious workers has replaced the traditional working class. This new class is characterised by insecurity and low pay for labour. Standing describes a variety of routes into the precariat, which includes part-time workers, temporary workers, unpaid or low-paid interns, independent contractors, and day labourers. ${ }^{47}$ All these categories are characterised by job insecurity, poor work conditions and few, if any, job protections. The term gig economy has come to represent the economic model of precarious work.

The academy has not been immune from this move towards precarious work. ${ }^{48}$ The direct cause of the increase in precarious work in academe has been the significant reduction in public spending for the support of universities, despite a significant increase in the numbers of students who are involved in tertiary education. "Between 1990 and 2010, state investment per student dropped by 26 percent, even as costs per student increased." 49

Kezar and her colleagues and others document the huge shift away from tenured and tenure track appointments to fixed-term contracts and low-paid part-time work.

Non-tenure track faculty members, now 70 per cent of the faculty within US higher education, average pay of $\$ 22,400$ for teaching eight courses, making less than most fast food workers and often with less job security and benefits than fast-food workers. ${ }^{50}$

The US is not alone in treating academics this way. A recent report on the status of academic employees in the UK include such statistics as: "Around $70 \%$ of the 49,000 researchers in the sector remain on fixed-term contracts, with many more living precariously on contracts which are nominally openended but which build in redundancy dates." ${ }^{51}$ 
Precarious employment has a variety of effects: psychological, practical and social. A recent survey by the UK University and College Union found, for example, that " $71 \%$ of respondents reported that they believed their mental health had been damaged by working on insecure contracts, while $43 \%$ reported that they believed their working conditions had damaged their physical health." 52

For refugee scholars, the implications of this movement toward precarious work has a particularly deleterious effect because it combines with insecure immigration status. We have seen the ways in which the UK and US system of immigration affects refugee academics' sense of insecurity and temporariness. Research indicates that recent migrants in general are more likely than others to be in temporary work and that official figures are likely to be an underestimate. ${ }^{53}$ As a researcher who works on the role of immigration in precarity puts it: "Precariousness can be created by putting people in a position of temporariness and status anxiety that makes it difficult for them to plan ahead. Through immigration controls, the state plays a direct role in this uncertainty." 54

In reality, many refugee scholars are not even able to take on precarious work, which is short-term in nature, on fixed contracts of hourly work, because they do not have the appropriate visa to do so. The exceptions are those who obtain asylum or, like Mehmet, who could have a visa through his wife.

The precarity of academic employment has a major effect on the post-fellowship trajectory of refugee scholars. This means that refugee scholars are competing with many thousands of academics for that shrinking percentage of jobs which are full-time, tenure track. The university employer needs to obtain a visa for the refugee scholar, and some universities would rather not undertake all the paperwork and expense involved, especially if there is another candidate for whom such effort is not necessary. Refugee academics are negatively affected by the relative shortage of such jobs as well as constrained by their immigrant status. Some refugee scholars who have the skills to do so, have simply given up trying to obtain work in academe and moved into other work; one refugee scholar I spoke to had become an accountant. Mohamed has gone into the importing business. Zizi, an Egyptian academic, who has a PhD in logistical supply and chain management, has been looking for any kind of job, including working at Starbucks.

Refugee scholars have to deal with the precarious nature of their jobs, like many young academics nowadays, flitting from one short-term job to the next (as long as their visa allows it). No sooner do they get one of these positions than they are looking for the next one, which is a job in itself. Looking for another position takes up a lot of time, and is stressful, especially for those still recovering from the persecution from which they fled. Also:

the displaced academics did not only lose their jobs and forfeit all rights to work in their home country, but the sudden and disruptive experience of exile also stripped them of their existing networks and professional seniority to a considerable extent. ${ }^{55}$ 
Some of the problems faced by refugee scholars finding employment after their short-term academic fellowships are less stark for those scholars who leave their countries of origin as students and who are educated in the host nations, because they may have more contacts to help them.

Refugee scholars are looking for employment with the added problem of visa precarity, in which they are constantly waiting for a decision on a visa, which may take a very long time. Or they are having to make immigration decisions which are tied to job options; for example, if someone applies for asylum, they cannot travel, and cannot therefore take another position in a different country without killing their chances for asylum in the host country.

Refugee scholars also have the additional problem of finding the time to work that results in publication, so they can be competitive on the job market with those who do not have such time constraints. Leila said:

They look at your publications, sitting back home I don't have a career like people here do. Back home, the foundations don't support research, so I write (on my own time). I worked 12 hours a day just for subsistence. It's a luxury to write academic articles.

This is the perfect storm. Refugee academics suffer all the problems of young, precarious academics, and also all the problems of those in visa insecurity. In both cases, the state has set the situation up to maximise the precarity. With less and less funding available to universities, more and more jobs are short-term, casual work, which affects those refugee scholars seeking work. The state has also set up an immigration system which is complicated, unfriendly and full of delay, requiring the gathering together of an array of suitable documents to prove whatever the authorities are looking for. Such a system exacerbates the feelings of precarity in those searching for stability. This affects refugee academics, who are even less able than other migrants to tolerate this psychological disruption, given their history of persecution and likely resultant PTSD.

The situation for refugee scholars of the 1930s and 1940s was easier in some ways. They arrived at a time when universities were expanding, rather than contracting as they are now. The initial visa was difficult to obtain, but more likely to be permanent, rather than the short-term visas often held by current refugee scholars. As mentioned above, they were more likely to be known quantities, with an international reputation, coming from recognised institutions, which would have made it a bit easier for them to obtain permanent academic positions. Current refugee academics have none of these advantages.

\section{Appendix}

Questions to ask Refugee Academics

1) Details of journey. Include questions about how they managed documentation. Did they have a visa, fellowship, etc. Did contacts with UK 
or other refuge country put them in danger? Did they use third-party contacts - for example get someone else to go to the consulate?

2) Details of education at home and in host country. How did their home education prepared them/or didn't, for what they do now?

3) What is the effect, if any, of their refugee status on their academic work?

4) How do they view themselves: As an academic first or a refugee first? How do (or don't) the two categories overlap?

5) Do they face a lack of understanding from their colleagues?

6) Do they plan to go back?

7) If so, how do they imagine their research? And do they have some particular purpose or goal they want to achieve in their homeland?

\section{Notes}

1 See e.g. Kezar et al., 2019; Petersen, 2020.

2 Quotes are from 14 of the interviewees.

3 See Bohmer and Shuman, 2007, 2018.

4 See Appendix.

5 Pachter, 1969-1970.

6 Lässig, 2017.

7 Lässig, 2017, 789.

8 Lässig, 2017, 783.

9 Tuori, in this volume.

10 Lebow, 2011, 549.

11 Lebow, 2011; Tuori, in this volume.

12 Özdemir, Mutluer, and Ozyürek, 2019, 240.

13 Lebow, 2011, 550-1; Pries, 2017.

14 Siegelberg, 2012, 286.

15 Wordsworth, 2019a.

16 Extending the Welcome: Long-term Approaches to Supporting Refugees and At-risk Scholars in Higher Education. 7-9 March 2019, University of Edinburgh.

17 Palca, 2019.

18 Lebow, 2011.

19 Lebow, 2011, 552.

20 Wordsworth, 2019a.

21 Lebow, 2011, 546.

22 See CARA Annual Report, 2018-19, 3.

23 Wordsworth, 2019a.

24 Wordsworth, 2019a.

25 Özdemir et al., 2019, 245.

26 Euronews, 2015.

27 UK Immigration Rules, s 339R, 2020.

28 Berthold, 2019.

29 Kmak and Farzamfar, in this volume.

30 Svensson, in this volume.

31 Dag, 2020, 63.

32 Dag, 2020, 63.

33 Vatansever, 2020.

34 Lebow, 2011. 


\section{Carol Bohmer}

35 Özdemir et al., 2019, 243.

36 Price, 2009.

37 Hathaway, 2018; Betts, 2013; McAdam, 2014.

38 Price, 2009.

39 Hathaway and Foster, 2014.

40 See Bergholm \& Toivanen in this volume for more on this situation.

41 Gibney, 2004.

42 Blitz, 2017; Bohmer and Shuman, 2018; Bergholm and Toivanen, in this volume.

43 Price, 2009.

44 See Bohmer and Shuman, 2018; Griffiths, 2012.

45 Wordsworth, 2019a.

46 Wordsworth, 2019b.

47 Standing, 2011.

48 Kezar et al., 2019; Vatansever, 2020.

49 Petersen, 2020.

50 Kezar et al., 2019, 1.

51 University and College Union, 2019.

52 University and College Union, 2019, 3.

53 Jayaweera and Anderson, 2008.

54 Anderson, 2013, 91.

55 Vatansever, 2020, 56.

\section{References}

Anderson, Bridget. 2013. Us and Them?: The Dangerous Politics of Immigration Control. Oxford: Oxford University Press.

Berthold, Megan. 2019. Personal Email Communication, December 17, 2019.

Betts, Alexander. 2013. Survival Migration: Failed Governance and the Crisis of Displacement. Ithaca and London: Cornell University Press.

Blitz, Brad. 2017. "Another Story: What Public Opinion Data Tell Us About Refugee and Humanitarian Policy." Journal on Migration and Human Security 5, no. 2: 379-400.

Bohmer, Carol, and Amy Shuman. 2007. Rejecting Refugees: Political Asylum in the 21 st Century. New York: Routledge.

Bohmer, Carol, and Amy Shuman. 2018. Political Asylum Deceptions: The Culture of Suspicion. London: Palgrave Macmillan.

CARA Annual Report. 2018-19. https://www.cara.ngo/cara-2018-19-annual-report/

Dag, Veysi. 2020. "Reflective Practice and the Contribution of Refugee-Researchers to Critical Understandings of the Refugee Integration Process." Oxford Monitor of Forced Migration 8, no. 2 (January): 62-67. Available at https://www.oxforcedmigration.com/post/reflective-practice-and-the-contribution-of-refugee-researchers.

Euronews. 2015. "Which Europeans Offer the Most Benefits to Migrants?” Euronews, September16,2015.https://www.euronews.com/2015/09/16/which-european-countriesoffer-the-most-social-benefits-to-migrants.

Gibney, Matthew J. 2004. The Ethics and Politics of Asylum. Cambridge: Cambridge University Press.

Griffiths, Melanie. 2012. "Vile Liars, and Truth distorters: Truth, Trust and the Asylum System.” Anthropology Today 28, no. 5: 8-12.

Hathaway, James C. 2018. "The Global Cop-Out on Refugees.” International Journal of Refugee Law 30, no. 4: 591-604. doi: 10.1093/ijrl/eey062. 
Hathaway, James C., and Michelle Foster. 2014. The Law of Refugee Status. Cambridge: Cambridge University Press.

Jayaweera, Hiranthi, and Bridget Anderson. 2008. "Migrant Workers and Vulnerable Employment: A Review of Existing Data." Centre of Migration Policy and Society (COMPAS). Report for the TUC Commission on Vulnerable Employment.

Kezar, Adrianna, et al. 2019. The Gig Academy: Mapping Labor in the Neoliberal University. Baltimore: Johns Hopkins University Press.

Lässig, Simone. 2017. "Strategies and Mechanisms of Scholar Rescue: The Intellectual Migration of the 1930s Reconsidered." Social Research 84, no. 4 (Winter): 769-807.

Lebow, Richard Ned. 2011. "German Jews and American Realism.” Constellations 18, no. 4: 545-566.

McAdam, Jane. 2014. “Conceptualizing ‘Crisis Migration’: A Theoretical Perspective.” In Humanitarian Crises and Migration: Causes, Consequences and Responses, edited by Susan F. Martin, Sanjula Weerasinghe, and Abbie Taylor, 28-49. London and New York: Routledge.

Özdemir, Seçkin Sertdemir, Nil Mutluer, and Esra Ozyürek. 2019. "Exile and Plurality in Neoliberal Times: Turkey's Academics for Peace." Public Culture 31, no. 2: 235-259.

Pachter, Henry. 1969-1970. “On Being an Exile.” Salamagundi 10-111 (Fall, Winter): $12-51$.

Palca, Joe. 2019. "While Others Saw Refugees, This German Professor Saw Human Potential." All Things Considered. NPR, February 9, 2017. https://www.npr.org/sections/goatsandsoda/2017/02/09/513700808/while-others-saw-refugees-thisgerman-professor-saw-human-potential.

Petersen, Charles. 2020. "Serfs of Academe.” New York Review of Books, March 12, 2020.

Price, Matthew E. 2009. Rethinking Asylum: History, Purpose and Limits. New York and Cambridge: Cambridge University Press.

Pries, Ludger. 2017. "Scientists as Forced Migrants and Refugees: What Can we Learn From the 1930s and 2010s?" Social Research 84, no. 4: 857-872.

Siegelberg, Mira L. 2012. "Scholarly Exiles.” History Workshop Journal 74 (Autumn): 283-288.

Standing, Guy. 2011. The Precariat: The New Dangerous Class. London: Bloomsbury Academic.

UK Immigration Rules, s 339R (accessed October 10, 2020). https://www.gov.uk/ guidance/immigration-rules/immigration-rules-part-11-asylum.

University and College Union. 2019. Counting the Costs of Casualisation of Higher Education. Key findings of a survey conducted by the University and College Union. Available at https://www.ucu.org.uk/media/10336/Counting-the-costs-of-casualisationin-higher-education-Jun-19/pdf/ucu_casualisation_in_HE_survey_report_Jun19.pdf.

Vatansever, Asl1. 2020. At the Margins of Academia: Exile, Precariousness, and Subjectivity. Leiden: Brill.

Wordsworth, Stephen. 2019a. Personal Email Communication, March 22, 2019.

Wordsworth, Stephen. 2019b. Lecture given at Pembroke College, Cambridge, UK, November 13, 2019. 